\title{
Biodiversity in Urban Governance and Planning: Examples from Swedish Cities
}

\author{
INGEMAR ELANDER*, ELISABET LUNDGREN ALM ${ }^{* *}$, \\ BJÖRN MALBERT ${ }^{* *} \&$ ULF G. SANDSTRÖM*
}

\begin{abstract}
One of the key agreements adopted at the Rio Conference in 1992 was the Convention on Biological Diversity (CBD). Both in practice and research biodiversity has been mainly addressed in a non-urban context, often discussed in relation to issues such as the depletion of rainforests and desertification. However, as more than half of the world population are urban dwellers, it is increasingly urgent to discuss the application of the concept of biodiversity within an urban context. Issues approached in this article are: What does it mean to talk about biodiversity in an urban context? Is biodiversity a meaningful goal for urban politics and planning? Is there empirical evidence of implementing biodiversity in urban politics and planning? After an introduction, the article is organized into four sections. In the second section the concept of biological diversity is defined with special reference to its application in an urban context. Biodiversity and its relationship to urban governance is the topic of the third section, followed by a section analysing examples of how this relationship is practised in selected Swedish cities. The final section highlights five major conclusions with regard to the application of biodiversity in an urban context: (1) that all cities studied have adopted overall 'green' policies, including biodiversity as one component; (2) that local coalitions in favour of implementing biodiversity have been established between employees at different offices, between employees and politicians, and between employees and NGOs; (3) that there are in all cases tangible signs of spatial patterns and structures that are favourable to biodiversity; (4) that urban biodiversity, for its successful implementation, needs to be related, and accommodated to other values given priority in current policymaking, such as recreation; (5) that mainstream biodiversity analysis should be complemented by an urban landscape approach. Finally, the article returns to the more general question of what biodiversity could and should mean in urban planning.
\end{abstract}

Keywords: Urban governance; urban planning; biodiversity in an urban context

\section{Introduction}

Invented discussion in the invented city G-town:

The developer: I have a great idea; I would like to build two new houses in that area.

The politician: We are always welcoming new developments in our city.

Ingemar Elander, Centre for Urban and Regional Studies (CUReS), Örebro University, Sweden, Tel: +46193030 69. Fax: +461930 34 84. Email: ingemar.elander@sam.oru.se. *Centre for Urban and Regional Studies (CUReS), Örebro University, Sweden. ${ }^{* *}$ Built Environment and Sustainable Development, Chalmers University of Technology, Göteborg, Sweden 
The planner: Let us see what area you mean and what plans we have for it.

The ecologist: I know that this area is an important part of the green structure of G-town.

The developer: Green structure, what is that?

The ecologist: It is the total amount of green spaces that can serve multiple functions in the city. In order to keep these functions, e.g. biodiversity, it is important that the greenways remain, from the city centre to the countryside.

The politician: But I guess it is possible to build and still keep some of these functions you are talking about?

The ecologist: No, it is impossible. Close to this area we have found a very rare herb that cannot survive if the park gets too small.

Politician: But we cannot let such a detail stop an important development! Is it not possible to build and leave some green spots beside the houses? Then we can have both green structure and new houses!

The developer: Yes, tell us the size of green area you need in order to save that herb and we will try to adjust our plans to that.

Most scientists seem to agree that we are experiencing an unprecedented decline in species diversity that has few parallels in the life history of the earth. Consequently, there is an increasing concern about today's accelerating loss of natural habitats, or biotopes, and their populations of species in the minds of many people as well as by governments and NGOs on all levels (COM, 1998; Heywood, 1995; Wilson, 1985; WCED, 1987). At the United Nations Conference on Environment and Development (UNCED) 1992 in Rio de Janeiro, world leaders agreed on a comprehensive strategy for 'sustainable development' - meeting current needs while ensuring that a healthy and viable world is left for future generations. One of the key agreements adopted at Rio was the Convention on Biological Diversity (CBD) (UNEP, 1992). This pact among the vast majority of the world's governments sets out commitments for maintaining the world's ecological underpinnings.

The CBD establishes three main goals: the conservation of biodiversity, the sustainable use of its components, and the fair and equitable sharing of the benefits from the use of genetic resources (UNEP, 1992). In article 6 in the CBD, each contracting party is requested to "develop national strategies, plans or programmes for the conservation and sustainable use of biodiversity ...". Parties concerned are also recommended to adapt existing strategies, plans or programmes to the measures set out in the CBD.

Both in practice and research, the application of the concept of biodiversity has been mainly addressed in a non-urban context. However, as more than half of the world's population and about three-quarters of the population in the developed countries are urban dwellers, it is increasingly urgent to discuss the application of the concept of biodiversity also with regard to towns and cities. As the introductory conversation well illustrates, urban planning practice is a matter of supporting the understanding between different 'languages' representing different types of understanding and knowledge. In other words, it can be seen as a struggle between different interests and opinions.

The dialogue between the invented actors raises a number of issues related to biodiversity in urban governance and urban planning practice: What does biodiversity mean, and what could and should it mean in an urban context? Which are the strategies formulated by local governments with regard to the green structure and biodiversity? 
How are these strategies implemented in urban design and planning practice and what are the resulting spatial patterns and structures? These are the questions addressed in this article.

The following section explores the concept of biodiversity, seeking the answer by drawing upon some of the theoretical literature in this field. Taking its point of departure in the concept of global environmental governance, the third section of the article raises the question whether 'biodiversity governance' is a concept that could make sense in empirical research and maybe also in policy formulation and implementation. The fourth section gives some examples from an empirical study of biodiversity planning in Swedish cities to show how the concept of biodiversity is applied in practice. The final section draws conclusions together and ends with a discussion of what biodiversity could and should mean in urban planning. Thus, the aim of the article is not to elaborate the concept biodiversity theoretically in all its dimensions but to investigate how the concept, given a core definition, is put into planning practice.

\section{Biodiversity: The Concept}

Biodiversity is one of several, more or less contested concepts in the new 'language of environment' (Myerson \& Rydin, 1996). Needless to say, sustainability as 'the umbrella concept' of this language is essentially contested and the target of different interpretations both in scientific and political discourses (Jacob, 1996). Originally, biological diversity referred to species or genetic diversity (Harper \& Hawksworth, 1995) but Norse et al., (1986) expanded its use to three levels: genetic (the genetic variation within species), species (the number of different species) and ecological (the variety of communities with their non-living environments) diversity. This three-level conceptualization of biological diversity has become commonplace and is also part and parcel of the Convention on Biological Diversity (CBD) (UNEP, 1992).

The three levels of biodiversity have a hierarchical nature (cf. Table 1). Overlapping and interfering with each other, actions at any given level will affect other levels in the hierarchy. Biological patterns and processes in the environment are also usually considered, for example, vegetation structure, nutrition flows and effects of disturbances like floods or human impacts. Biodiversity is also dependent on different biological scales, i.e. within-habitat diversity or the number of species within a community, between-habitat diversity or changes in species composition along an environmental gradient, and diversity of several environmental gradients at the landscape level (Noss, 1990; Wiens, 1989). Adding to this complexity, biodiversity is far from a static entity. Changes occurs constantly causing new genetic variation and reduction or loss of species, and habitat degradation.

\section{Why Biodiversity?}

Preserving biodiversity is important for several reasons. From a deep green, biocentric point of view the strongest argument is the ethical one, i.e. as human beings we have no right to change and violate nature, thereby causing the extinction of species. From an anthropocentric point of view, aesthetic and historical arguments in favour of biodiversity are often raised (Nordström et al., 2002), as well as arguments related to public health and life quality. Biodiversity is also regarded as important for the sake of biological and medical research (Jernelöv \& Kågesson, 1992). Notably, pests are excluded from the biodiversity policy agenda (UN, 1992. p. 248), although from a strictly scientific point of view they are manifestations of biodiversity. Recommendations very much in line with CBD are put 


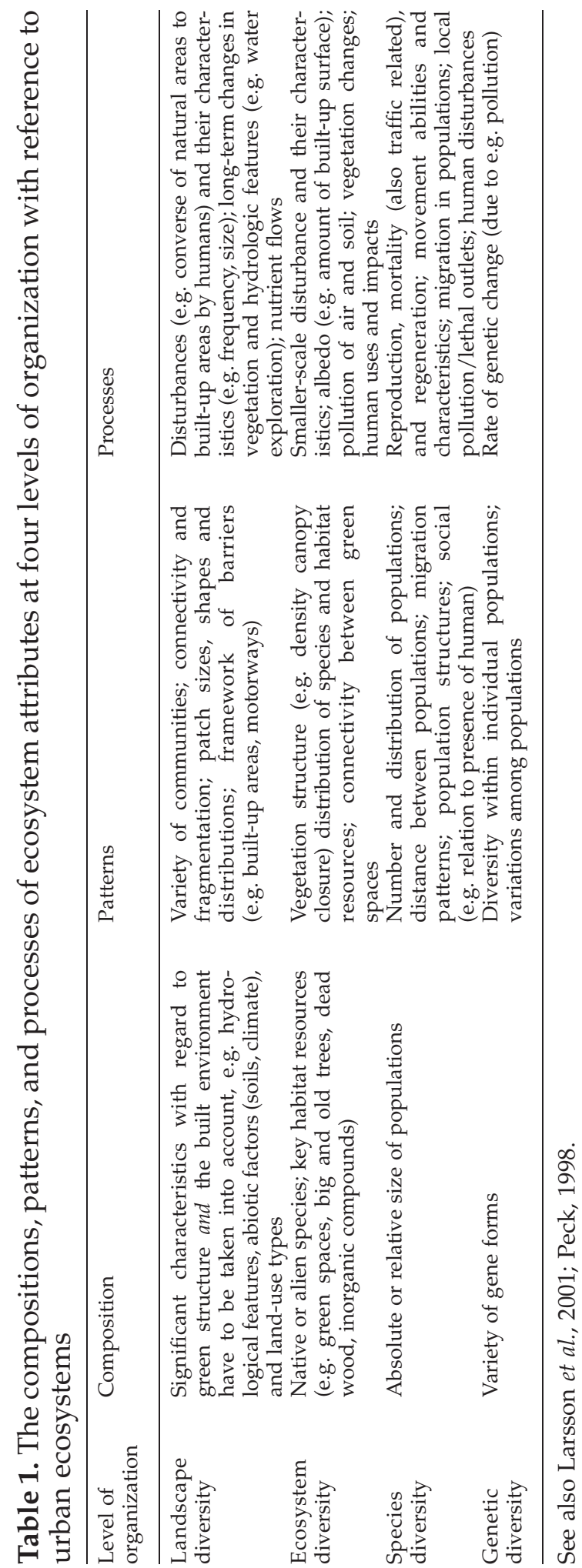


forward in the Agenda 21, where it is also stated that national strategies for preserving biodiversity should be developed and integrated into national plans (UN, 1992).

\section{The Biodiversity Concept in the Urban Landscape}

The largest single threat to biodiversity worldwide is the outright destruction of habitat, along with habitat alteration and fragmentation of large habitats into small patches (Mittermeier \& Forsyth, 1997). As the urbanization process is worldwide and expected to grow (UN, 2001), there is a need to investigate the influence of urban sprawl on biodiversity (e.g. water explorations, species pools or nutrient flows) and the importance of green spaces and other habitat resources in urban settings.

To enhance migration between habitats at various biological scales, greenways like hedgerows, waterways or other linear habitats in a dissimilar matrix that connect the habitats have to be preserved or laid out (Forman, 1995). In the urban environment, greenways in the form of green wedges or streams may penetrate the urban area connecting urban green spaces like parks and other natural-like areas. Preferably, the greenways should be in connection with the surrounding landscape. This will, for example, favour diversity of species in the urban landscape because in a patchy environment many species are spatially divided populations (Merriam, 1998).

Thus, a long-term persistence of species in a fragmented landscape depends heavily on the presence of unoccupied suitable habitats, which means that empty patches suitable for different species should be protected in physical planning. In one way or another, human activities always interact with natural processes to produce patterns and changes observed in the landscape. Patterns such as connectivity and fragmentation, vegetation structure and species distribution are attributes to pay attention to at different biological levels as are changes in land use and exploitation of ground and surface water (Forman, 1995). As the biodiversity in the urban landscape depends on how well the urban green structure is developed and if it has connections to the surrounding landscape, these three concepts are interconnecting and should be paid attention to when biodiversity is discussed in an urban landscape approach (cf. Sandström et al., in press).

Urban growth means that the natural environment is increasingly occupied with buildings, traffic routes and other constructions, implying a gradient of human influence from city centres towards rural areas in the periphery (Yokohari et al., 2000). As a consequence, the scale of urban lifestyle is not restricted to towns and cities. It has a much wider extension, thus affecting biodiversity at the within-habitat level as well as at the landscape level. Therefore, aside from the genetic, species and ecological levels, the study considers an additional fourth level of biodiversity to be relevant in urban planning, namely 'the landscape'. Arguably, the analysis of local government experience later in the article will give empirical support to this standpoint, which will then be looked at again and developed in the concluding section. The following section will first locate biodiversity within the context of environmental governance in general and its urban dimension in particular.

\section{Governing Urban Diversity}

The Convention on Biological Diversity is one of the three main global sustainable development conventions, either signed (climate) or conceived (desertification) at UNCED.

It addresses issues that range from ecosystem protection to the exploitation of genetic resources, from conservation to justice, from commerce to scientific 
knowledge, from the allocation of rights to the imposition of responsibilities. It is, therefore, criss-crossed by widely differing political dynamics. Indeed, its three goals of conservation, sustainable use, and benefit-sharing make it perhaps the first true sustainable development convention. (Le Prestre, 2002, p. 1)

Although there is no full consensus either about the magnitude of biodiversity loss or about its consequences, in a number of respects the CBD is based on the premise that biodiversity is decreasing, and that governments at all levels should form strategies to preserve and stimulate biodiversity. This plea for a multi-level policy approach to favour biodiversity is a clear expression of what is commonly called global environmental governance (Hempel, 1996, p. 5; Lipschutz \& Mayer, 1996, p. 249; Young, 1996, p. 2).

Environmental governance is one instance of a broader trend commonly referred to as "governing without government" (Rhodes, 1997, p. 47) or governance by "self-organising, inter-organizational networks" (Kooiman, 1993; Rhodes, 1997, p. 53). Disregarding the many alternative, more or less overlapping, definitions and applications of the concept of governance found in the literature, one may at least identify a common understanding of some basic traits, for the particular purpose of this article delimited to environmental governance. Hempel, for example, defines global environmental governance as:

the people, political institutions, regimes, and non-governmental organisations (NGOs) at all levels of public and private policy making that are collectively responsible for managing world affairs. (Hempel, 1996, p. 5).

In the same vein, Young (1996), in an edited volume titled Global Environmental Change and International Governance, defines governance as:

a social function whose performance is crucial to the viability of all human societies; it centres on the management of complex interdependencies among actors (whether individuals, corporations, interest groups, or public agencies) who are engaged in interactive decision-making and, therefore, taking actions that affect each other's welfare. (p. 2)

Thus, environmental governance is a multi-level phenomenon. Depending on the particular ecological issue at hand, it is located at one or several levels: household, community/neighbourhood, city/town, region/nation and/or global. Environmental governance at the city/town level has often been analysed using Local Agenda 21 as an example, although there are also other studies focusing upon environmental policies not formally linked to the Agenda (see, for example, the special issue on multi-level governance in Local Environment, 9(5), October, 2004). Far from covering the environmental governance agenda as a whole, biodiversity is one of several important topics. The article will now briefly identify how biodiversity as a policy goal has been addressed at the supra-national level as well as the European and Swedish central government levels before narrowing the focus to the urban policy level.

\section{Biodiversity as a Global Concern}

The UN report Our Common Future was a milestone that placed biodiversity on the political agenda (WCED, 1987). The report discusses how biodiversity can benefit mankind in terms of species, ecosystem and genetic diversity. The living and non-living parts of our environment essential for the development of society were given special attention to in the report. Following from Our Common Future, UNCED came up with a strong support for preserving biodiversity through the CBD and the Agenda 21 
(UN, 1992; UNEP, 1992). So far, the CBD has been ratified by 188 national governments (Convention on Biological Diversity, 2005). This makes the CBD one of the most significant and far-reaching environmental treaties ever.

\section{The CBD in the European Union}

The European Community approved the CBD in Rio in June 1992 and ratified it in December 1993. In the following years and in accordance with article 6 in the CBD, the European Community developed a strategy for sustainable use of biodiversity. In February 1998, the European Commission adopted a Communication on a European Biodiversity Strategy and in June the same year the Council endorsed the strategy, as did the Parliament in October. The aims of the strategy are:

to anticipate, prevent and attack the causes of significant reduction or loss of biodiversity at the source. This will help both to reverse present trends in biodiversity reduction or losses and to place species and ecosystems ... at a satisfactory conservation status, both within and beyond the territory of the European Union, (COM, 1998, p. 3).

The strategy is developed around four major themes, namely: (1) conservation and sustainable use of biodiversity; (2) sharing of benefits arising out of the utilization of genetic resources; (3) research, identification, monitoring and exchange of information; and (4) education, training and awareness. As a member state of the European Union since 1995, Sweden is expected to take her responsibility for implementing the EU strategy.

\section{The CBD in Sweden}

Sweden signed the CBD in June 1992 and in December the following year it was ratified, meaning that Sweden has adopted the CBD definition of biodiversity (Hedlund \& Eriksson, 1993). A central component in Swedish environmental policy is the implementation of the CBD, i.e. the protection and maintenance of biodiversity (Government Bill, 1994/1995, number 230; The Environmental Code, 1998; Framtidens miljö - allas vairt ansvar, 2000). Thus, biodiversity is one of five basic values underpinning Swedish environmental policy. The other four are related to people's health, preservation of cultural historical values, preservation of the long-term productive capacity of the ecosystem, and securing efficient management of the natural resources. Although some of the 15 Swedish National Environmental Objectives adopted by the Swedish parliament in 1999 are closely related to biodiversity, the government has stated that by 2005 biodiversity will acquire an independent status as an additional environmental objectives (number 16) (Naturvårdsverket, 2003).

In 2001 the Swedish parliament decided to allocate SEK 440 million (about $€ 40$ million) to research on biodiversity for the period 2002-04. About 250 research projects are currently investigating different aspects of biodiversity as one crucial investment on the road towards sustainability. This massive research effort well illustrates the priority assigned to biodiversity by the Swedish government. In the preamble of a booklet presenting the points of departure of this research, biodiversity is located on the commonly used three levels of biodiversity, i.e. the ecosystem, the species and the genetic level (cf. Table 1). In general, the official Swedish approach to biodiversity expresses a broad understanding of the scientific discourse in this field, including a small but growing interest in the urban aspects of biodiversity (see www.biologiskmangfald.nu). To what extent, and how this understanding manifests itself in policy practice is of course another question. 


\section{Biodiversity in Swedish Urban Governance}

In line with the CBD and Agenda 21, in 1993 the Swedish government gave the Swedish Environmental Protection Agency the mission to make a land survey concerning the state of biodiversity in the country (Bernes, 1994). As a follow-up of this land study, five authorities received a new government mission in 1994 to develop sectoral action plans on how to preserve and use biodiversity in a sustainable way. ${ }^{1}$ The action plan adopted by the Swedish Board of Housing, Building and Planning deals with biodiversity in built-up areas (Emanuelsson et al., 1996). One of the Swedish National Environmental Quality Objectives is 'Good Urban Environment', stating that:

... areas of unspoiled nature and green spaces close to built-up areas, which are easily accessible, should be protected in order to meet the needs for recreation, local farming and healthy local climate. Biodiversity should be preserved and enhanced (Government Bill, 1997/1998, number 145).

The Swedish Planning and Building Act (PBL) is currently in the preparatory stage of revision, and it seems quite clear that biodiversity will become one of the values to take a prominent position in the forthcoming Act. However, the question remains how biodiversity will be operationally defined in an urban context and what could and will be done to promote it.

When focusing upon biodiversity in urban governance and planning, first it should be remembered that local government in Sweden has a very strong potential for discretionary action compared to its counterpart in most other countries. Thus, local government in Sweden has a firm constitutional foundation backed up by a set of laws regulating local government relations to central government and to the citizens. Local government has its own fiscal rights, its political organization is based on direct and proportional elections, and there is a huge staff of professionals administering a quite comprehensive welfare system and delivering social services to the citizens. All in all, local government is something more qualified than just deconcentrated state administration, i.e. it is a case of local 'self-government' (Elander \& Montin, 1990).

Narrowing the perspective to ecological issues, local government in Sweden is a crucial actor when it comes to sewerage and waste treatment, recycling, green public purchase, green consumption, green accounts etc., and thus it may itself initiate and support citizen initiatives leading towards ecological sustainability in a general sense. However, with regard to energy, traffic, heavy infrastructure, environment protection and agriculture, the scope of local government action is narrower. In these areas, business interests, the central state and extra-national actors such as the European Union and trans-national companies are actors of a much heavier weight (Elander \& Lidskog, 2000). For this reason, it is impossible to calculate with precision the effects upon biodiversity caused by urban politics and planning in general, although by looking at measures undertaken with the explicit aim of increasing biodiversity in an urban setting an answer could gradually be found.

To find the character of biodiversity governance in practice, two empirical studies have been undertaken. Drawing upon these studies, the following section raises and answers the following questions. Is biodiversity mentioned as a goal in municipal policy documents, for example, in the municipal comprehensive plan or in the Local Agenda 21? If so, how is it defined? Are there any operational sub-goals formulated? Are there any hints about its implementation in terms of an organizational structure and particular actors? Do the implementing actors belong to the local government organization, or are 
there also actors representing interests in local civil society, for example, associations of ornithologists or field biologists? Are there any instruments created so as to evaluate the effects on biodiversity of particular policy measures? What are the similarities and differences in outcome of biodiversity governance between the cities?

\section{Biodiversity and Urban Planning Practice}

In this section, the implementation of biodiversity in urban planning practice is illustrated by examples from Swedish cities. The discussion draws heavily upon two empirical studies. The first is an interview study with key actors in four Swedish cities. The second is a brief survey of biodiversity in planning documents in six Swedish cities and two regions. The two studies give an empirical input to the subsequent discussion about the limitations of identifying biodiversity on the three levels commonly defined in environmental governance.

\section{Urban Green Structure and Biodiversity}

The physical structure of the urban landscape can be divided into four categories: (1) buildings; (2) streets and squares; (3) technical structure (such as electricity supply and water or sewer systems), and (4) green structure. The latter are defined as all nonhardened and undeveloped land. The green structure is multifunctional, ranging from social to ecological functions. In relation to biodiversity, green structure may increase the connectivity between habitats in different biological scales in the urban landscape.

The urban landscape is characterized by habitats representing early successive stages, invasion by alien species, low degree of connectivity, more island-like habitats (i.e. increased fragmentation), and deviation of abiotic factors compared to rural areas (Niemelä, 1999; Trepl, 1995). Examples of the latter are temperature, cloudiness and precipitation increase in urban areas while relative humidity and wind speed decrease (Hough, 1995; Landsberg, 1970). Due to the difference in materials in urban and non-urban environment with paved surfaces and concrete in the former, heat energy is absorbed and reflected back to various surfaces, which creates an urban heat island (Hough, 1995). This increase in temperature attracts many species requiring higher temperatures (McDonnell et al., 1997) but may also be unfavourable for other species, e.g. snails (Baur, 1994). Despite these differences between urban and rural ecosystems, and the intense influence of humans in the former, both are governed by the same ecological laws (Niemelä, 1999).

\section{Implementing Biodiversity in Urban Planning Practice}

This section is based on empirical findings from four Swedish cities: Stockholm, Göteborg, Malmö and Örebro. During spring 2004, interviews with key persons in the four cities were carried out. As the knowledge about biodiversity in an urban context is still poor, the overarching aim of this survey was to find out if and how biodiversity is handled in urban planning practice. Approximately five local employees took part in each interview. The answers are structured around five themes; expressions of biodiversity in planning and policy documents, biodiversity within the organization and its political weight, the local organization related to green issues, the green structure planning in relation to NGOs and citizens, and finally, the importance of dedicated staff.

Stockholm. Stockholm is the biggest Swedish municipality with approximately 750000 inhabitants. Due to a huge housing deficit, the development pressure on the land is very strong. Stockholm has a policy for biodiversity dating back to 1999, which states that "all species worth saving shall be protected in vital populations". However, this policy is 
not widespread throughout the local administration. When talking about biodiversity in planning, it is most often connected to the recreational aspects of urban green structure.

An interesting urban application of biodiversity is to be found in biotope mapping, a practice where both physical and temporal aspects of biodiversity have been in focus (Löfvenhaft, 2002). Biotope mapping, based on aerial photos and key biotopes, is used in order to visualize the specific location and distribution of valuable biotopes in the urban landscape. In order to identify and argue more strongly about valuable places and qualities in the urban landscape, the Stockholm planners have been forced to develop their arguments, and thus their documents in a direction which gives priority to the efficiency of implementation. According to local planners, the biotope maps are very useful as a basis for planning as they visualize biological values in a new manner, thus facilitating communication between different professional groups. Aside from the biotope maps, two other kinds of maps have been developed; i.e. sociotope maps showing the distribution of social qualities of the green structure within each district of Stockholm, and a recycling map indicating the use of resources. Taken together, these three kinds of maps constitute the Green Map of Stockholm; i.e. a map expressing the state of the green values in this urban setting (Ståhle \& Sandberg, 2000).

Despite the biotope maps, biodiversity has a very weak position in the city administration and it is impossible to identify any local politician willing and capable of pushing the issue into strategic contexts. Issues related to green structure and biodiversity are handled within the urban planning office, where several professions work together depending on the character of the current planning tasks. Ecological competence is spread all over the city administration, and there is an 'ecologist group' which meets regularly to discuss common issues. Although biodiversity and green structure are integrated into the overall planning process, the respondents complain about the lack of more strategic work concerning how to handle the green issues. For example, the respondents ask for identifications of areas, which, from a green and biodiversity point of view, can be improved or deteriorated by the ongoing policy of urban densification. The current political majority in the city council is a coalition dominated by Social Democrats, whereas in the former electoral period the majority was a non-socialist coalition. In neither case have green structure and biodiversity been issues of high priority.

In relation to NGOs, biodiversity is quite a strong argument. Local sections of the Swedish Nature Conservation Society and the Swedish Tourist Society are very keen on arranging meetings and seminars when building plans are in conflict with green interests in the Stockholm region. Their main arguments are related to their interest in protecting recreational possibilities. Among the citizens, there is a quite strong movement concerning the quality of backyards. Local competitions, directed at selecting the most beautiful backyard, are regularly arranged by the housing companies together with the local government administration.

In addition to the importance of dedicated persons, several respondents emphasize the production of the biotope map as a very crucial and important step towards better integration of biodiversity knowledge into the planning process. The next step, to fully make use of this knowledge, is identified as a matter of deliberation, i.e. of accommodating different views, thus facilitating communication in the local planning situation.

Göteborg. Göteborg with its 460000 inhabitants is the major city of the West Sweden Region and the second biggest city in Sweden. The city has a history of trade and manufacturing industry. However, in the late 1970s the city faced massive job losses, mainly due to the closure of shipyards. Struggling to transform itself into a successful post-industrial city, 
the city of Göteborg has worked hard at promoting itself as a knowledge and event city, while keeping a substantial part of its industrial base. The current political majority, a coalition between Social Democrats, the Left Party and the Green Party, thus promotes a growth orientated policy in partnership with the city administration, the knowledge industry and the universities (von Sydow, 2004, Ch. 5).

Due to the mountainous terrain and the fact that the city owns vast amounts of undeveloped land with a potential for exploitation, Göteborg is a green city with a high proportion of green spaces per capita. The inner city, developed by Dutch immigrants during the 17th century, is surrounded by several green belts and parks, which are part and parcel of the city's traditional profile. The green structure issues are spread over several offices and political boards. The Real Estate Office, the Urban Planning Office, the Environment Protection Office, the City Museum and the Park and Nature Office are all involved in the planning of the green structure. However, it is only the last three that have biological competence. Thus, there is no specific office having the main responsibility for issues of biodiversity.

The green structure plan of Göteborg, which constitutes a part of the comprehensive plan, has not been updated since 1993 and is neither well-known nor widespread. This plan gives a very comprehensive and mainly theoretical picture of the most valuable green areas as defined from a combined recreational and scientific point of view. The plan describes biodiversity in a very general and abstract way. In 1979, a Nature and Culture Conservation Programme was launched, which has not been updated. This is something officials complain about. They miss a document where all the green space of the city is clearly visible. There is no document whatever adjusting the national and regional environmental goals to local conditions.

Green issues have a weak position in the overall policy package of Göteborg, possibly explained by the abundance of green spaces. Many officers experience a lack of engaged and competent politicians. They ask for better integration of different issues in the planning process, which could bridge cultural and language barriers between different professions. The impression is also that it is difficult to carry through green policies depending on the municipality being afraid of raising the maintenance costs. On the other hand, EU directives such as Nature 2000 (Council directive 92/43/EEC), are experienced as very powerful as they are supported by clear quantitative criteria and connected to severe sanctions. The park and nature office has recently launched a sociotope programme, inspired by the pioneer work in Stockholm as described earlier in this article.

With regard to voluntary organizations, the tradition of local protests is quite strong in the city, formed either ad hoc when issues have arisen or as more permanent organizations based in certain city districts. Green issues are commonly treated as one of several aspects. Local sections of the Swedish Nature Conservation Society have taken an interest in issues related to the public use of recreational areas, using scientific arguments for specific biotopes and species. Other NGOs and citizens in a broader sense are taking part in discussions about planned changes in certain areas, especially when densification or new road plans are in conflict with public green areas. However, the study was not able to identify any one person especially committed to biodiversity.

Malmö. The urban diversity strategy of Malmö is very different from the two cases analysed so far. Malmö is the third biggest city in Sweden, situated in the southern part of the country. Despite the fact that Malmö has the lowest amount of green space per inhabitant in Sweden and is surrounded by an intensive and quite flat agriculture region, the city has been known as 'the city of parks'. The strategy in Malmö has been to increase, 


\section{Elander et al.}

develop and secure the total amount of green spaces and values. Thus, the focus is on both quantitative and qualitative aspects.

In the Malmö Green Plan, the word 'biodiversity' is being exchanged for 'biological variation', which is further developed and adapted to the character of the different districts and types of nature that can be found in and around the city (Grönplan för Malmö, 2003). The degree of biological deficit is expressed in maps for each urban district. An obvious reason for this work being executed in Malmö is the fact that the city is surrounded by an agricultural landscape where the nature varies less than within the city itself. If there is to be a higher degree of biological variation in the area overall, the work has to start within the city and grow further outside its borders when and where it is possible. This situation differs substantially from that in the cities further north in Sweden where the urban surroundings are still varied as compared to most other urban environments. Thus, what is striking in the case of Malmö is the importance of the regional perspective, which is strongly emphasized in the city's biodiversity planning strategy. The administrative structure does not cover the city's urban landscape, which extends over a whole geographical region, i.e. yet another example of the classical mismatch between a functional and an administrative region.

Discussion about green issues between NGOs, citizens and the municipality is only sporadic and biodiversity is not an issue in focus in the political debate between the Social Democratic majority (with support of the Left Party) and the non-socialist minority. Many administrative officers experience a lack of engaged and competent politicians. As a very strong and good example, they put forward the competent, long term and very consistent work performed by the city gardener. According to the respondents, the gardener has successfully moved green issues into the most powerful corridors of the city administration and thus made a viable green structure as one of five objectives for the urban development of Malmö.

Örebro. Situated in the semi-wooded 'biogeographic region' in south-central Sweden, Örebro, with its 125000 inhabitants, is the seventh biggest municipality in the country. The landscape surrounding the city is flat lowland with farmland and remnants of mainly broad-leaved and mixed deciduous forests. A river passes through the city centre on its way to Lake Hjälmaren, the fourth biggest lake in Sweden, situated east of the city. The political majority is similar to the one in Göteborg. Due to its favourable location as a link between densely populated regions both in and outside Sweden, the former small industrial town Örebro has developed into an important centre for transport, retail trade, education, hospital care and other services. The city of Örebro is surrounded by green areas, partly stretching into it like green fingers. In the eastern part there are two nature reservations, one of which is classified by the EU as a Nature 2000 protection area, i.e. an area worth special attention in terms of green values (Council directive 92/43/EEC). By the river, in the western part of the city, there is a former agricultural area that is very much like an English park in character.

The political majority in the city council the last few years has been a coalition of Social Democrats, the Left Party and the Green Party. Biodiversity is mentioned as a priority policy goal in the municipal comprehensive plan, and in the Local Agenda 21. However, according to local government officers, implementation of this policy has been less radical than the rhetoric says, mainly because it has not been regarded as something that can be operationalized in daily practice. Statements found in policy documents say that:

... the use of land and water shall be performed in such a way that these natural resources are protected for the future, and that there are no threats to 
biodiversity and to the natural and the cultural landscape. (Örebro municipality, 2002, p. 16)

... biodiversity should be preserved and developed in both planned parks and in forests close to the densely built-up areas. (Orebro municipality, 2004)

Although priority given to green issues in the planning process has shifted from time to time, compared to many other towns and cities in Sweden, environmental policies in Örebro are well regarded. The city is now developing a green plan for the urban landscape, arguing in favour of green structure from three different perspectives, i.e. the social, the cultural and the ecological. The plan is expected to be completed/adopted before summer 2005 .

In the city administration, there are two departments responsible for green structure planning, namely the Technical Department and the City Planning Department. In order to implement biodiversity in the planning process, the senior biologist and the senior ecologist in 1997 were transferred from the Environmental Service Office to the City Planning Department. Today this department has the main responsibility for looking after biodiversity issues in the planning process.

The Örebro local section of the Swedish Nature Conservation Society is a very active participant in the planning process. The same goes for the local association of ornithologists, especially when it comes to planning issues concerning the vast area around the river delta (named Oset in Swedish). Strikingly, a case study in progress on politics and planning around this area bears the working title 'The power of the ornithologists' (Olsson, 2005). Thus, when issues of densification, traffic and building of new housing estates appear on the agenda, there are always lively debates in local media, often raising arguments relating to green structure. Thus, most citizens in Örebro seem to put a high value on their urban green structure, and distrust arguments in favour of densification.

\section{What can be Learned from these Experiences?}

A common experience from the cities studied is that all respondents, independent of profession, expressed satisfaction with this investigation. As they identified the handling of biodiversity in urban planning as problematic, they found it constructive to discuss the subject.

Another common experience is connected with the Swedish planning system. Swedish cities have the main responsibility for physical planning and also have the legal and personnel means to take this responsibility. Thus their degree of discretion in the field of planning is quite substantial. As a consequence it is not surprising to find great variation in policy implementation, for example, when it comes to green structure planning.

A third experience is that there are huge differences between local governments, depending on the specific relations between local political and administrative structures. If the politicians have an interest in promoting biodiversity or any other issue of planning, and also make clear political decisions and statements about it, the support for and acceptance of local innovative planning initiatives taken by the planners will also become much stronger.

\section{Where and How is Biodiversity Used in Planning Documents?}

In order to locate the extent to which the concept of biodiversity is being absorbed into the Swedish planning system, a brief survey was carried out of planning documents in six Swedish cities and two regions. The following comments are based on conclusions from this survey. 
In Sweden there are three official planning levels: the regional plan, the comprehensive plan and the local plan. Of these three, only the local plan is legally binding. While both the local plan and the comprehensive plan are compulsory for the long-term structural planning in all Swedish municipalities, the regional plan is only compulsory in the Stockholm region. Apart from these planning levels, green structure plans are becoming increasingly common and elaborated in the Swedish context. They are often integrated parts in the comprehensive plan (Sandström, 2002).

The survey shows some interesting features in urban planning practice. First, the plans are commonly focused upon very general aspects of biodiversity. Second, in local plans, biodiversity issues are hardly mentioned at all unless there is a specific protection interest in the area. Third, it becomes quite evident that there are severe problems in translating biodiversity into the physical aspects of development projects, which are the core matter of urban planning practice, as well as into the appropriate planning scale.

Thus, biodiversity as a subject in planning documents is most commonly treated at the comprehensive and green structure plan level, while it is infrequent at the regional level, and almost non-existent at the local level. To give an example, in the Örebro comprehensive plan it is stated that:

The use of ground and water should not threaten the long-term productive ability, the biodiversity and the natural and cultural landscape. There should be a restricted use of sources that are not renewable. Outlet of pollutants should be limited with regard to the health of nature and man. (Örebro municipality, 2002, p. 16)

This example shows how the concept of biodiversity is used in a very general way, giving no clear guidelines, and leaving the task of translating these general statements to potential actors in the implementation process. The same situation is found in Göteborg where interview respondents thought that the comprehensive plan came too early when trying to implement guidelines for a certain issue, whereas the local plan came too late. This dilemma has to do with the way the Swedish planning system functions. While the comprehensive planning level tends to become too comprehensive, the local plan, which is focused on providing a framework for specific development actions gives little room for applying abstract green structure intentions as formulated in the comprehensive plan. Thus, there is a need for a stronger connection between these planning levels. Arguably, one way of doing this could be the introduction of the concept of urban landscape into the planning process, both at the comprehensive and the local plan level. This possibility is now discussed further in the following, concluding section of the article.

\section{Conclusions}

Starting with five conclusions drawn mainly on the basis of these empirical studies, the final section ends by discussing the general question of what biodiversity could and should mean in urban planning.

First, all the cities studied have adopted overall 'green' policies, including biodiversity as one component. They have also produced planning documents, including ideas about how to maintain and develop green structures with an explicit aim, and a potential to stimulate urban biodiversity. However, if biodiversity is to become implemented, it is important that policies with that aim are adjusted to natural as well as political conditions in the local context. This becomes very evident and clear in the case of Malmö, where adaptation to the surrounding landscape and the local urban culture has produced 
a concept that seems less abstract and more practice-orientated than biological diversity as such, i.e. biological variation.

Second, it has become evident that the establishment of local coalitions between employees in different departments, between employees and politicians, and between employees and NGOs are implementation tools of great potential power. To be helpful in planning practice, general theoretical knowledge of biological diversity has to be related to and integrated with knowledge of the local context. Employees involved in the planning process can, for example, make use of green issue reports produced by NGOs. These reports are often very skilfully written, also visualizing new perspectives of green structure in the urban landscape.

Third, although it has not been possible to illustrate this in the article due to lack of space, in all the cities studied there are some tangible signs of spatial patterns and structures that are favourable to biodiversity, such as the water corridor of 'River City Örebro' ( $\AA$-staden Örebro), and the many parks of Malmö. Göteborg is a fairly green city by tradition, although, at a time of strong pressure from the urban growth coalitions, the urban landscape is not very generous towards green structure. This is even more the case for Stockholm where the green structure is challenged by strong demands for space to be used for housing and other buildings, and for the transport system.

Fourth, many of the actors involved in the planning process are not fully aware of the fact that biodiversity is one of several values to be given priority in the urban environment. The studies show that although it is sometimes possible to harmonize different interests, this may at other times be difficult or even impossible. The successful cases are those where the responsible employees have found a complementary interest to biodiversity, thus managing to identify and make use of connections between different interests. As an example, this strategy is very often valid for recreational aspects in relation to biodiversity. Where it is important to secure recreational values, these values can often be connected to biodiversity or other biological values.

Finally, most of the strategies formulated concerning biodiversity are very difficult to implement in urban planning practice, due to the fact that the issues are raised at a level that is too general and abstract. This observation gives support to the conclusion that within urban planning practice the three levels of biodiversity (ecosystem, species and genetic variation) should be expanded to a fourth one: the urban landscape diversity level (Table 1). Arguably, using the landscape level would facilitate the adaptation of biodiversity to the planning of urban structures. This conclusion does not follow automatically from these empirical studies, and therefore this argument will be developed a little further.

\section{Bringing the Landscape Level into the Planning Process}

So far, biodiversity has been quite successfully introduced into the Swedish planning system at the comprehensive planning level. However, to be able to translate the abstract principles of biodiversity into a detail plan, thus making design principles becoming supportive to biodiversity in practice, knowledge must be made adjustable to the local and regional context. To achieve this aim, the genetic, species and ecological levels of biodiversity by themselves have shortcomings, even if taken together.

Apart from lacking functional connection between current planning levels, there is also a crucial time aspect. As the comprehensive plan is only advisory, and the local plan is preparing for specific action, the two planning levels have different time perspectives, i.e. long term in the first case, and short term in the second. Thus, long-term concerns for biodiversity may be undermined by short-term actions undertaken to the benefit of 


\section{Elander et al.}

alleged economic rationality. Arguably, bringing the landscape level into the planning process would make explicit the potential conflicts, not only between different levels and time horizons but also between different values and actors in concrete implementation situations. In line with this there is also great need for landscape architects to develop an urban orientation (Lundgren Alm, 2001).

\section{What Biodiversity could and should mean in Urban Planning}

Returning to the invented discussion at the beginning of this article, it illustrates quite a common picture of a local planning situation. Deadlocks such as those shown in the dialogue are likely to occur. However, the studies here indicate that such blocking situations might be avoided. To reach more constructive planning methods it is important to see biodiversity in a broader context where it becomes one interest among others. Further, it is crucial that the actors involved are open-minded in order to find solutions to the challenges of the local situation. Examples of such challenges could be the need for more dwellings, the need for changes in the transportation system or the need to maintain and secure certain landscape values. If time for broad and open deliberation is given at the beginning of a planning process, conflicts could be identified and visualized at an early stage. This would facilitate the development of strategies showing different alternatives where the involved values and interests are dealt with in a common learning process. Arguably, the actors would then become more aware of the conflicts between different perspectives, and thus more willing to make efforts to reach a common strategy. ${ }^{2}$

Stepping back a little from these empirical studies, the final reflection is that the recent political interest in biodiversity should be related to the dominant view of nature in society. Today, very few people are directly connected with agricultural production, as was the case just a century ago in most West European countries. We tend to look at nature as something separated from ourselves (Hedrén, 2002; Hornborg, 2003). This way of thinking dates back to the scientific discoveries during the enlightenment. Our strong confidence in scientific knowledge has enforced the separation of man from nature and thus made it possible to conceal the political dimension of the use of nature. This development implies that issues about nature are often handled outside the political institutions, by a specially trained expertise, which tends to postulate that different values can be reduced to a common basic scale of values. Following this line of thinking many natural scientists, and other experts, would argue that the scientific community by itself is well prepared to offer objective knowledge for implementing biodiversity, thus evading the political question of the complex relationships between society and nature (Lidskog, 2000).

However, political conflicts could and should not be hidden in a planning process where certain values and interests are implicitly given priority to the detriment of others. The ecomodernist belief that economic growth and ecological sustainability easily go hand in hand should not be taken for granted. Thus, there is no 'natural' solution to the question of how to implement biodiversity in the urban environment. As illustrated by the vignette dialogue, the only way forward is by developing new practices and reflecting upon these practices in deliberative communication processes. Studying such processes, and bringing knowledge from others' experience into it may contribute to better understanding and more efficient practices with regard to developing biodiversity in an urban context.

\section{Acknowledgements}

This article draws heavily upon a research project lead by one of the authors, Elisabet Lundgren Alm. A more extensive report will be published in Swedish. The authors are 
grateful to financial support from the Swedish Research Council for Environment, Agricultural Sciences and Spatial Planning (FORMAS). Thanks are also due to a number of referees, who raised several crucial questions for consideration with regard to an earlier version of the manuscript.

\section{Notes}

1. The authorities were the Swedish Board of Housing, Building and Planning, the National Board of Fisheries, the National Board of Forestry, the Swedish Environmental Protection Agency, and the National Board of Agriculture.

2. Indications of how a truly consensual planning practice could be developed without denying underlying conflicts between the involved actors are given in Larsson \& Elander (2002).

\section{References}

Baur, B. (1994) Thermal radiation from a city causes extinction of a snail, Urban Nature Magazine, 2, pp. 6-7.

Bernes, C. (Ed.) (1994) Biologisk mångfald i Sverige. En landstudie (Biological diversity in Sweden. A land study) (Solna, Swedish Environmental Protection Agency).

Boverket (1999) Bebyggelselandskapet $i$ Sverige. Tätorternas areella utveckling 1960-1995. (The built landscape in Sweden. The territorial development of villages, towns and cities 1960-1955) (Karlskrona).

COM (1998) Communication of the European Commission to the Council and to the Parliament on a European Community Biodiversity strategy (Luxembourg, EC).

Convention on Biological Diversity (2005) Available at http://www.biodiv.org/world/parties.asp (accessed 25 March 2005).

Council directive 92/43/EEC of 21 May 1992 on the conservation of natural habitats and of wild fauna and flora (Brussels, Office for Official Publications of the European Communities).

Elander, I. \& Montin, S. (1990) Decentralization and control. Central and local government relations in Sweden, Policy and Politics, 18(3), pp. 165-180.

Elander, I. \& Lidskog, R. (2000) The Rio Declaration and subsequent global initiatives. Ch. 2 in: N. Low, B. Gleeson, I. Elander \& R. Lidskog (Eds) The Urban Environment in the Global Economy after the Rio Declaration (London and New York, Routledge).

Emanuelsson, U., Johannesson, R., Borgegård, S.-O. \& Benskjöld, U. (1996) Aktionsplan för biologisk mångfald vid byggd miljö (Action plan for biological diversity in the built environment) (Karlskrona, The Swedish Board of Housing, Building and Planning).

Forman, R.T.T. (1995) Land Mosaics. The Ecology of Landscapes and Regions (Cambridge, Cambridge University Press).

Framtidens miljö—allas vårt ansvar (The environment of the future — the responsibility of all) (2000) Betänkande från Miljömålskommittén. SOU 2000: 52 (The Swedish Government Official Reports).

Government Bill 1994/1995: 230. Kommunal översiktsplanering enligt plan-och bygglagen (Local government structure planning according to the Planning and Building Act).

Government Bill, 1997/1998: 145. Miljöpropositionen—Svenska miljömål (Stockholm, The Environmental Bill— Swedish Environmental Quality Objectives).

Grönplan för Malmö (The Malmö Green Plan) (2003) (Malmö, Malmö stad).

Harper, J.L. \& Hawksworth, D.L. (1995) Preface, in: D.L. Hawksworth (Ed.) Biodiversity. Measurement and Estimation, pp. 5-12 (London, Chapman \& Hall).

Hedlund, L. \& Eriksson, M.O.G. (1993) Biologisk mångfald (Biological Diversity), Report No. 4138 (Stockholm, Swedish Environmental Protection Agency).

Hedrén, J. (Ed.) (2002) Naturen som brytpunkt: om miljöfrågans mystifieringar, konflikter och motsägelser (Nature as a breaking point. On the mystifications, conflicts and contradictions) (Eslöv, Symposion).

Hempel, L.C. (1996) Environmental Governance (Washington DC, Island Press).

Heywood, V.H. (Ed.) (1995) Global Biodiversity Assessment (Cambridge, Cambridge University Press).

Hornborg, A. (2003) Modernitet och ekologisk revolution (Modernity and ecological revolution), in: A. Öckerman \& E. Friman (Eds) Hela världen: samhälleliga och kulturella perspektiv på miljökrisen (All the world: societal and cultural perspectives on the environmental crisis), pp. 317-328 (Lund, Studentlitteratur).

Hough, M. (1995) Cities and Natural Processes (London and New York, Routledge).

Jacob, L. (1996) Sustainable Development. A Reconstructive Critique of the United Nations Debate (Göteborg, Göteborgs universitet). 
Jernelöv, A. \& Kågesson, P. (1992) Biologisk mångfald i Sverige. Hur klarar vi uppdraget? (Biological diversity in Sweden. How do we manage the commitment?) Miljövårdsberedningens rapport 1992:3 (Stockholm, Miljövårdsberedningen).

Kooiman, J. (1993) Modern Governance. New Government. Society Interactions (London/Newbury Park/New Delhi, Sage).

Landsberg, H.E. (1970) Man-made climatic changes, Science, 170, pp. 1265-1268.

Larsson, J. \& Elander, I. (2002) Consensus, democracy and the land surveyor in the Swedish cadastral executive procedure, Planning Theory \& Practice, 2(3), pp. 325-342.

Larsson, T.-B., Angelstam, P., Balent, G., et al. (2001) Biodiversity evaluation tools for European forests, Ecological Bulletins, 50.

Le Prestre (Ed.) (2002) Governing Global Biodiversity. The Evolution and Implementation of the Convention on Biological Diversity (Aldershot, Ashgate).

Lidskog, R. (2000) Scientific evidence or lay people's experience? On risk and trust with regard to modern environmental threat, in: M. Cohen (Ed.) Risk in the Modern Age: Social Theory, Science and Environmental Decision-making, pp. 196-224 (London, MacMillan).

Lipschutz, R.D. \& Mayer, J. (1996) Global Civil Society and Global Environmental Governance (Albany, State University of New York Press).

Local Environment (2004) 9(5) Special Issue: Multi-level Governance.

Löfvenhaft, K. (2002) Spatial and Temporal Perspectives on Biodiversity for Physical Planning. Examples from Stockholm, Sweden (Stockholm, Stockholm University).

Lundgren Alm, E. (2001) Stadslandskapets obrukade resurs. Om grönstrukturens potential och synliggörande i en hållbar stadsutveckling (The unused resource of the urban landscape. On the potential and visibility of the green structure on the road towards sustainable urban development) (Göteborg, Chalmers tekniska högskola).

McDonnell, M.J., Pickett, S.T.A., Groffman, P., Bohlen, P., Pouyat, R., Zipperer, W.C., Parmelee, R.W., Carreiro, M. \& Medley, K. (1997) Ecosystem processes along an urban-to-rural gradient, Urban Ecosystems, 1, pp. 21-36.

Merriam, G. (1998) Biodiversity at the population level: a vital paradox, in: F.L. Bunnel \& J.F. Johnsson (Eds) Policy and Practices for Biodiversity in Managed Forests: The Living Dance, pp. 45-65 (Vancouver, UBC Press).

Mittermeier, R.A. \& Forsyth, A.B. (1997) Setting priorities for biodiversity conservation. one organisation approach, in: G.K. Meffe \& C.R. Carroll (Eds) Principles of Conservation Biology, 2nd edn., pp. 141-149 (Sunderland, MA, Sinauer Associates).

Myerson, G. \& Rydin, Y. (1996) The Language of Environment. A New Rhetoric (London, UCL Press).

Naturvårdsverket (2003) Miljömålen. Available at http://miljomal.nu/om_miljomalen/vadhander.php (accessed 23 April 2003).

Niemelä, J. (1999) Ecology and urban planning, Biodiversity and Conservation, 8, pp. 119-131.

Nordström Källström, H. \& Ljung, M. (2002) Att kommunicera biologisk mångfald (Communicating biological diversity). Report 6 (Uppsala: SLU, Institute for Landscape Planning).

Norse, E.A., Rosenbaum, K.L., Wilcove, D.S., et al. (1986) Conserving Biological Diversity in our National Forests (Washington: DC, The Wilderness Society).

Noss, R.F. (1990) Indicators for monitoring biodiversity: a hierarchical approach, Conservation Biology, 4, pp. 355-364.

Olsson, J. (2005, forthcoming) The Power of the Ornithologists. Empowering the Advocacy Coalition Framework, (manuscript in progress).

Örebro municipality (2002) Översiktsplan för Örebro kommun (Comprehensive plan for Örebro municipality) (Örebro, Örebro kommun).

Örebro municipality (2004) Örebro miljömål (Environmental objectives for Örebro) (Örebro, Örebro kommun).

Peck, S. (1998) Planning for Biodiversity: Issues and Examples (Washington DC, Island Press).

Rhodes, R.A.W. (1997) Understanding Governance: Policy Networks, Governance, Reflexivity and Accountability (Oxford, Oxford University Press).

Sandström, U.G. (2002) Green infrastructure planning in urban Sweden, Planning Practice and Research, 17(4), pp. 373-385.

Sandström, U.G., Angelstam, P. \& Khakee, A. Ecological diversity of birds and the structure of urban green space, Landscape and Urban Planning, in press.

Ståhle, A. \& Sandberg, A. (2000) Sociotopkarta över parker och andra friytor i Stockholms innerstad: metod och resultat (Sociotope map of parks and other green open space in inner Stockholm: methods and results) (Stockholm, Stadsbyggnadskontoret \& Gatu- och fastighetskontoret).

Sydow, Åsa von (2004) Exploring Local Governance in Urban Planning and Development (Stockholm, Royal Institute of Technology).

The Environmental Code (1998) SFS 1998:808 and SFS 1998:811 (Stockholm). 
Trepl, L. (1995) Toward a theory of urban biocoenoses—some hypotheses and research questions, in: H. Sukopp, M. Numata \& A. Huber (Eds) Urban Ecology as the Basis of Urban Planning, pp. 3-21 (The Hague, SPB Academic).

UN (1992) Agenda 21 (New York, United Nations).

UN (2001) World Urbanisation Prospect: The 1999 Revision (New York, The United Nations Population Division). UNEP (1992) Convention on Biological Diversity (Nairobi, UNEP Environmental Law and Institutions Programme Activity Centre) www.greenscom.com.

WCED (1987) Our Common Future (New York, Oxford University Press).

Wiens, J. (1989) The Ecology of Bird Communities (Cambridge, Cambridge University Press).

Wilson, E.O. (1985) The biological diversity crisis, BioScience, 35, pp. 700-706.

Yokohari, M., Takeuchi, K., Watanabe, T. \& Yokota, S. (2000) A framework for the conservation of rural ecological landscapes in the urban fringe area in Japan, Landscape and Urban Planning, 29, pp. 103-116.

Young, O. (1996) Introduction. The effectiveness of international environmental governance systems, in: O. Young, G.J. Demko \& K. Ramakrishna (Eds) Global Environmental Change and International Governance, pp. 1-30 (Hanover and London, University Press of New England). 